Research article

\title{
Phytosociological studies of the sacred grove of Kanyakumari district, Tamilnadu, India
}

\author{
S. Sukumaran ${ }^{1}$, A. Pepsi ${ }^{1}$, D. S. SivaPradesh ${ }^{1}$ and S. Jeeva ${ }^{2}$ \\ ${ }^{1}$ Department of Botany and Research centre, Nesamony Memorial Christian College, Marthandam, \\ Kanyakumari-629165, Tamilnadu, India \\ ${ }^{2}$ Department of Botany and Research centre, Scott Christian College, Nagercoil, Kanyakumari-629003, \\ Tamilnadu, India
}

*Corresponding Author: sukunmec@gmail.com

[Accepted: 28 March 2018]

\begin{abstract}
Sacred groves are forest patches conserved by the local people through religious and cultural practices. These groves are important reservoirs of biodiversity, preserving indigenous plant species and serving as asylum of Rare, Endangered and Threatened (RET) species. The present study was carried out in Muppuram coastal sacred grove of Kanyakumari district to reveal the plant diversity, structure and regeneration pattern of trees using quadrate method. About 102 plant species were recorded from the total area ( $0.2 \mathrm{ha})$ of the grove studied. The vegetation of the grove clearly indicates tropical dry evergreen forest. Malvaceae was the dominant family. Young plant species were dominating than older ones $(>160 \mathrm{~cm})$. To avoid the rapid environmental degradation of the sacred grove, conserving the groves is urgent and it is necessary to conduct more researches on this grove as well as other groves of the district.
\end{abstract}

Keywords: Floristic diversity - Regeneration - Conservation - Sacred groves - Traditional.

[Cite as: Sukumaran S, Pepsi A, SivaPradesh DS \& Jeeva S (2018) Phytosociological studies of the sacred grove of Kanyakumari district, Tamilnadu, India. Tropical Plant Research 5(1): 29-40]

\section{INTRODUCTION}

The degradation of tropical forests and destruction of habitat due to anthropogenic activities are the major causes of the decline in global biodiversity (Sukumaran et al. 2008, Rabha 2014). Therefore, in many areas conservation of biodiversity and maintaining landscape productivity are being taken up on a priority basis, for the restoration of degraded lands by planting fast-growing indigenous and native plant species (Solbrig 1991). One of the important challenging tasks before the ecologists is to understand the relationship between biodiversity and functioning of ecosystems (Younes 1992, Davis \& Richardson 1995). The high rate of extinction of tropical species is aggravated by the clearing of forestland and conversion into agricultural cropland. Harvesting non-timber forest products, selective extraction of plants and animals, biological invasion and monocultural practices are serious threat to biodiversity (Myers 1993, Phillips 1995, Phillips 1997, Sundarapandian \& Swamy 1997, Sundarapandian \& Swamy 2000, Swamy et al. 2000, Mishra et al. 2004, Sundarapandian et al. 2005, Mehra et al. 2014, Rastogi et al. 2015, Sarkar \& Devi 2017). Reorientation of the psyche of people towards maintaining biodiversity is of utmost importance (Ramakrishnan et al. 1998).

Despite the vast and varied flora in Southern Western Ghats, information on the biodiversity of the sacred groves is not explored to a desired level. The past workers such as Raj \& Sukumaran (1997), Jeeva et al. (2005a, b), Jeeva et al. (2006), Prakash et al. (2006) have studied phytodiversity of the region. Nayar (1959), Sundarapandian \& Swamy (1997), Swamy et al. (2000) have paid much attention on forests other than sacred groves of Kanyakumari district. Due to religious beliefs, patches of vegetation are left untouched known as sacred groves. The importance and its conservation status have recently gained more importance, hence several studies have been carried out to evaluate the biodiversity of sacred groves throughout the country (Gadgil \& Vartak 1976, Burman 1992, Rodgers 1994, Balasubramanian \& Induchoodan 1996, Tripathi 2001, Khumbongmayum et al. 2005, Deepa et al. 2017). The plant wealth and conservation potential have acknowledged sacred groves as "mini biosphere reserves" (Gadgil \& Vartak 1975). 
The survey was largely limited to an enumeration of plants and distribution only neglecting quantitative analysis which is essential for evolving strategies for their conservation. Qualitative studies on plant diversity and conservation status of some sacred groves of Kanyakumari district were studied by Sukumaran and his coworkers (Raj \& Sukumaran 1997, Sukumaran \& Jeeva 2008, Sukumaran et al. 2008). In view of this, the present study was conducted to investigate the plant diversity, structure and regeneration pattern of trees and highlights botanical significance, because of the nature of forest communities largely dependent on the ecological characteristics in sites, species diversity and regeneration status of species.

\section{MATERIALS AND METHODS}

Study site

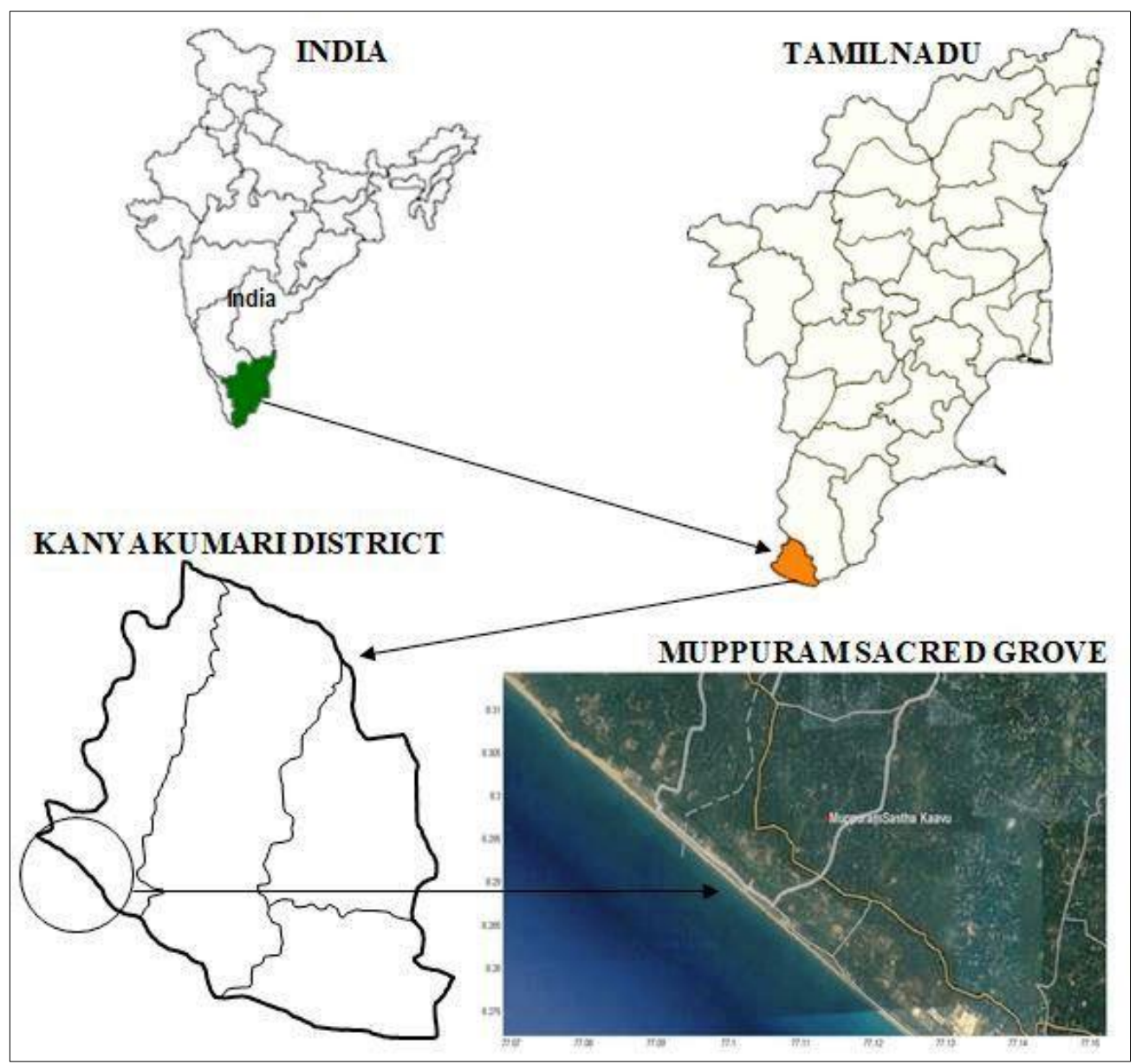

Figure 1. Map of the study area.

The present study was conducted in Muppuram sacred grove of Kollencode town panchayat $\left(08^{\circ} 17^{\prime} 51^{\prime \prime} \mathrm{N}\right.$ and $77^{\circ} 06^{\prime} 50^{\prime \prime}$ E) of Kanyakumari district, Tamilnadu, India (Fig. 1), which lies close to the boundary of Kerala towards its west. The soil of this grove is sandy because Arabian Sea is just away from this grove. Climate is warm and humid. Rainfall varies from $1030 \mathrm{~mm}$ to $3100 \mathrm{~mm}$. The grove is governed by Tamilnadu Devasam board. Tamil and Malayalam are the languages spoken by the people. Christians and Hindus form the sizeable percentage. Nadar is the major community and other communities are Meenavar, Aasari, Chackarevars, Nair, Paravas and Kerala Mudalis. The main deity of this grove is Ayappa and other deities worshipped are Nagaraja, Pillaiyar and Brahma. The mother tree (Sthalavrisha) is Manilkara hexandra. Annual festival is celebrated every March for 3 days. Devotees used to do milk and fruit abishekam to the deities. Sweet Pongal will be offered to the deities and then to the devotees. Priest is from Nair community and worship is open to all. A perennial pond is located in the western part of the grove, which has a separate ecosystem enriched with microalgae, aquatic plants, fishes, planktons and so on. Apart from the pond there are two wells, one is inside the grove, the water from this well mostly used for the Poojas and another one is outside where devotees take bath and enter in the grove. The water present in both wells are believed to cure diseases. Migratory birds from Australia come to this grove every year for reproduction. 
Vegetation of the grove

The general floristic composition and physiognomy of vegetation of the Muppuram sacred grove resembles low level tropical dry evergreen forest. Undisturbed areas of this grove shows luxuriant vegetation comprising several storeys of trees mixed with shrubs, lianas and herbs. The ground layer is rich in litter and macro fungi and hence the soil is abundant in humus which favors the growth of seasonal members usually thick populated species preferring humus and love shade for growth. Aquatic plants and algae grow gregariously on the perennial pond of the grove. Floristic variations have occurred due to human and animal interferences and also climatic and edaphic changes. The exact physiological implication behind this high humidity is not experimentally proved though it may be described to very high transpiration rate of leaves of these floral elements.

\section{Plant Diversity and Community Attributes}

Phytosociological studies were carried out by quadrat sampling method as per Mishra (1968), Kershaw (1973). Twenty quadrats of $10 \mathrm{~m} \times 10 \mathrm{~m}$ were randomly laid for trees ( $\geq 20 \mathrm{~cm}$ gbh). Sixty quadrats of $5 \mathrm{~m} \times 5$ $\mathrm{m}$ each for shrubs and saplings and 60 quadrats of $1 \mathrm{~m} \times 1 \mathrm{~m}$ size for studying herbs and seedlings were laid within the same $10 \mathrm{~m} \times 10 \mathrm{~m}$ quadrats those were laid for the study of trees. Density (trees ha ${ }^{-1}$ ) and basal area values were calculated for each species. Importance value index (IVI) of each species was calculated as per Phillips (1959). Similarly species richness, dominance and diversity were determined by computing the index of species richness (Margalef 1958); Shannon diversity index (Shannon \& Weiner 1949); Simpson dominance index (Simpson 1949) and Evenness index (Pielou 1969) were calculated using the formula as given in the reference cited above.

$$
\begin{gathered}
\text { Frequency }(F)(\%)=\frac{\text { Number of quadrats of occurrence of a species }}{\text { Total number of quadrats studied }} \times 100 \\
\text { Density }(\%)=\frac{\text { Total number of individuals of a species }}{\text { Total number of quadrats studied }} \times 100 \\
\text { Basal cover }=\text { Density } \times \text { Average basal area of individuals of a species } \\
\text { Abundance }(\mathrm{A})=\frac{\text { Number of individuals of a species }}{\text { Number of quadrats of occurrences of the species }} \times 100 \\
\text { Relative Dominance }(\mathrm{RDm})=\frac{\text { Total basal area for a species }}{\text { Total basal area for all species }} \times 100 \\
\text { Relative Density }(\mathrm{RD})=\frac{\text { Number of individuals of a species }}{\text { Total number of all individuals }} \times 100 \\
\text { Relative Frequency }(\mathrm{RF})=\frac{\text { Frequency of a species }}{\text { Sum frequencies of all species }} \times 100 \\
\text { Importance value index (IVI) }=\text { RDm }+ \text { RD }+\mathrm{RF} \\
\text { Whitford's index }=\frac{\text { Abundance }(\mathrm{A})}{\text { Frequency }(\mathrm{F})} \times 100 \\
\text { Species }
\end{gathered}
$$

where, $\mathrm{S}=$ Total number of species, $\mathrm{N}=$ Total number of individuals and $\ln =\log 2$.

$$
\text { Diversity index (Shannon \& Weiner 1949) }\left(H^{\prime}\right)=\sum_{i=1} p i \operatorname{In} p i
$$

where, $H^{\prime}=$ Shannon-Weiner diversity index, $p i=$ Proportion of IVI of a species i.e. $(n i / N)$. 


$$
\text { Dominance index (Simpson 1949) }(\mathrm{Cd})=\sum_{i=1}^{S}(p i)^{2}
$$

\section{Species Accumulation Curve}

Species accumulation curve was plotted against area for both the plots. After randomizing the samples for 50 times using Estimates (Version 6.0b1, 2000), the Chao1 species number generated for the 0.1 ha subplots $(10 \mathrm{~m}$ $\times 10 \mathrm{~m}$ ) were used to raise the species accumulation curve.

\section{Taxonomic Evaluation}

Plants species were collected and identified taxonomically with the help of different floras (Beddome 18681874, Gamble \& Fischer 1915-1935) and by using field keys devised by Pascal \& Ramesh (1987).

The Herbaria of Botanical Survey of India, Southern Circle, Coimbatore; Kerala Forest Research Institute, Peechi; Tropical Botanical Garden and Research Institute, Trivandrum, Kerala and the Department of Botany, Nesamony Memorial Christian College, Marthandam were consulted for correct identification of plant specimens. The nomenclature of species follows the regional flora. Lists of endangered, rare and endemic plants found in the sacred groves were prepared with the help of published works of Ahmedullah \& Nayar (1986), Ramesh \& Pascal (1991). The voucher specimens were made as per the methods and deposited in the herbarium of Nesamony Memorial Christian College, Marthandam, Kanyakumari, Tamilnadu, India.

\section{RESULTS AND DISCUSSION}

\section{Species composition and their distribution pattern}

A total of 102 species were identified in 0.2 ha area of the sacred forest studied. Five species remained unidentified, included two species of orchids. Phytodiversity of the recently studied sacred groves from various part of the country shows that a total of 111 species were recorded from four sacred groves of (Ramanujam \& Cyril 2003), 180 species were reported from Sendirakillai sacred grove of Cuddalore district, Tamilnadu (Gnanasekaran et al. 2012), 94 plant species were recorded from Koraput district, Odisha (Debabrata et al. 2014). A total of 245 flowering plants were recorded from Vallikaattu sacred grove of Kozhikode, Kerala (Sreeja \& Unni 2016), 119 species, representing 8vulnerable, 12 endemic and 3 near threatened species were reported from Thrissur district, Kerala (Deepa et al. 2016). In the study area, trees were distributed in three distinct strata, namely canopy (> $15 \mathrm{~m}$ height), sub canopy (8-15 m height) and under canopy $(<8 \mathrm{~m} \mathrm{height).}$ The canopy layer was composed of Artocarpus heterophyllus, Artocarpus hirsutus, Ficusbenghalensis, Ficus religiosa and Schleichera oleosa, while Albizia lebbeck, Hydnocarpus wightianus, Litsea glabrata, Mangifera indica, Strychnos nux-vomica, Swietenia mahagoni and Tamarindus indica constituted subcanopy stratum. Flacourtia indica, Drypetes sepiaria, Manilkara hexandra, Magnolia champaca, Morinda coreia, Tamilnadiauliginosa, Santalum album, Semecarpus travancorica, Syzygium densiflorum and Vitex negundo formed the under canopy layer. The undercanopy layer composed of rich vegetation due to overhead canopy layer suppressing the growth of under canopy (Jamir \& Pandey 2003). Species richness (number of species per $100 \mathrm{~m}^{2}$ area) clearly indicated that the community was mosaic of high- and low-diversity fragmented forest (Fig. 2). This appears to be the result of combined effect of non-extreme stable environmental conditions and gap phase dynamics within the forest (Whittaker 1975, Upadhaya et al. 2004).

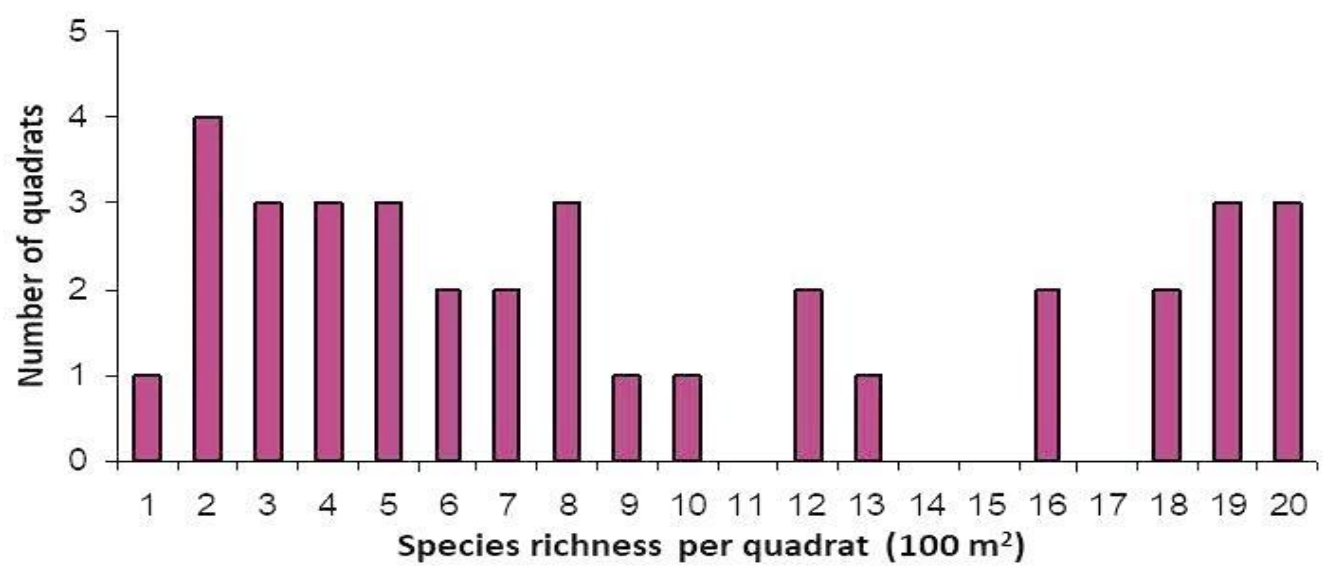

Figure 2. Spatial distribution of tree species richness in the study area. 
Table 1. Important value indices (IVI) of plant species recorded in the tropical dry forest fragment of south west coast of Kanyakumari district.

\begin{tabular}{|c|c|c|}
\hline Botanical names & Family & IVI \\
\hline \multicolumn{3}{|c|}{ Trees } \\
\hline Adenanthera pavonina $\mathrm{L}$. & Leguminosae & 12.6 \\
\hline Albizia lebbeck (L.) Benth. & Leguminosae & 6.77 \\
\hline Anacardium occidentale L. & Anacardiaceae & 9.1 \\
\hline Annona squamosa L. & Annonaceae & 2.94 \\
\hline Areca catechu $\mathrm{L}$. & Arecaceae & 3.48 \\
\hline Artocarpus heterophyllus Lam. & Moraceae & 8.91 \\
\hline Artocarpus hirsutus Lam. & Moraceae & 3.89 \\
\hline Buchanania barberi Gamble. & Anacardiaceae & 2.62 \\
\hline Carica papaya $\mathrm{L}$ & Caricaceae & 1.75 \\
\hline Cocos nucifera $\mathrm{L}$ & Arecaceae & 3.89 \\
\hline Drypetes sepiaria (Wight \& Arn.) Pax \& K. Hoffm. & Putranjivaceae & 49.5 \\
\hline Ficus benghalensis L. & Moraceae & 24.58 \\
\hline Ficus religiosa $\mathrm{L}$. & Moraceae & 7.6 \\
\hline Flacourtia indica (Burm.f.) Merr. & Salicaceae & 7.63 \\
\hline Gliricidia sepium (Jacq.) Walp. & Leguminosae & 23.48 \\
\hline Glycosmis pentaphylla (Retz.) DC. & Rutaceae & 3.41 \\
\hline Hydnocarpus wightianus Blume & Achariaceae & 3.71 \\
\hline Litsea glabrata Hook.f. & Lauraceae & 2.31 \\
\hline Magnolia champaca (L.) Baill. ex Pierre & Magnoliaceae & 3.1 \\
\hline Mangifera indica $\mathrm{L}$. & Anacardiaceae & 2.73 \\
\hline Manilkara hexandra (Roxb.) Dubard & Sapotaceae & 25.19 \\
\hline Morinda coreia Buch.-Ham. & Rubiaceae & 21.28 \\
\hline Phyllanthus emblica L. & Phyllanthaceae & 1.97 \\
\hline Psidium guajava $\mathrm{L}$. & Myrtaceae & 1.73 \\
\hline Santalum album $\mathrm{L}$. & Santalaceae & 6.33 \\
\hline Schleichera oleosa (Lour.) Merr. & Sapindaceae & 12.04 \\
\hline Semecarpus travancorica Bedd. & Anacardiaceae & 1.78 \\
\hline Sterculia foetida $\mathrm{L}$. & Malvaceae & 1.78 \\
\hline Sterculia guttata Roxb. ex G.Don & Malvaceae & 1.76 \\
\hline Strychnos nux-vomica L. & Loganiaceae & 3.8 \\
\hline Swietenia mahagoni (L.) Jacq. & Meliaceae & 2.2 \\
\hline Syzygium densiflorum Wall. ex Wight \& Arn. & Myrtaceae & 1.89 \\
\hline Tamarindus indica $\mathrm{L}$. & Leguminosae & 12.92 \\
\hline Tamilnadia uliginosa (Retz.) Tirveng. \& Sastre & Rubiaceae & 17.8 \\
\hline Thespesia populnea (L.) Sol. ex Correa & Malvaceae & 1.78 \\
\hline Vitex negundo L. & Lamiaceae & 1.76 \\
\hline \multicolumn{3}{|c|}{ Shrubs } \\
\hline Barleria prionitis L. & Acanthaceae & 17.08 \\
\hline Breynia retusa (Dennst.) Alston. & Phyllanthaceae & 11.18 \\
\hline Bryophyllum pinnatum (Lam.) Oken & Crassulaceae & 9.4 \\
\hline Calotropis gigantea (L.) Dryand. & Apocynaceae & 11.5 \\
\hline Carissa spinarum $\mathrm{L}$. & Apocynaceae & 8.36 \\
\hline Citrus aurantiifolia (Christm.) Swingle & Rutaceae & 11.62 \\
\hline Ehretia microphylla Lam. & Boraginaceae & 17 \\
\hline Euphorbia antiquorum L. & Euphorbiaceae & 10.64 \\
\hline Gardenia resinifera Roth & Rubiaceae & 16.94 \\
\hline Hibiscus rosa-sinensis L. & Malvaceae & 17.44 \\
\hline Ixora brachiata Roxb. & Rubiaceae & 18.3 \\
\hline Lantana camara $\mathrm{L}$. & Verbenaceae & 25.88 \\
\hline Nerium oleander L. & Apocynaceae & 7.17 \\
\hline Ochna obtusata DC. & Ochnaceae & 32.67 \\
\hline Ophiorrhiza mungos L. & Rubiaceae & 30.67 \\
\hline Opuntia dillenii (Ker Gawl.) Haw. & Cactaceae & 14.52 \\
\hline Pavetta zeylanica (Hook,f.) Gamble & Rubiaceae & 24.54 \\
\hline Tabernaemontana alternifolia $\mathrm{L}$. & Apocynaceae & 15.1 \\
\hline
\end{tabular}


Abrus precatorius $\mathrm{L}$.

Bridelia stipularis (L.) Blume

Cadaba fruticosa (L.) Druce

Cansjera rheedii Blanco

Capparis divaricata Lam..

Capparis sepiaria $\mathrm{L}$.

Capparis zeylanica $\mathrm{L}$.

Carissa spinarum $\mathrm{L}$.

Cayratia japonica (Thunb.) Gagnep.

Cissampelos pareira $\mathrm{L}$.

Cissus vitiginea $\mathrm{L}$.

Grewia serrulata DC.

Hugonia serrata Lam.

Jasminum angustifolium (L.) Willd.

Morinda umbellata L.

Pueraria montana var. lobata (Willd.) Sanjappa \& Pradeep.

Pyrenacantha volubilis Hook.

Strychnos colubrina Blume.

Tetracera akara Merr.

Tetrastigma canarense (Dalziel) Gamble

Uvaria narum A.DC.

Ziziphus oenopolia (L.) Mill.

Aerva lanata (L.) Juss.

Andrographis paniculata (Burm.f.) Nees

Apluda mutica L.

Blepharis maderaspatensis (L.) B.Heyne ex Roth

Boerhavia diffusa L.

Ceropegia spiralis Wight

Commelina benghalensis L.

Commelina erecta $\mathrm{L}$.

Dendrobium macrostachyum Lindl.

Eragrostis amabilis (L.) Wight \& Arn.

Eragrostis patula (Kunth) Steud.

Gloriosa superba L.

Hemidesmus indicus (L.) R.Br. ex Schutt.

Justicia japonica Thunb.

Justicia tranquebariensis L.f.

Knoxia sumatrensis (Retz.) DC.

Microstachys chamaelea (L.) Mull.Arg.

Mimosa pudica L.

Ocimum tenuiflorum L.

Oplismenus compositus (L.) P.Beauv.

Perotis indica (L.) Kuntze

Plumbago zeylanica L.

Sansevieria roxburghiana Schult. \& Schult.f.

Sida acuta Burm.f.

Sida cordifolia $\mathrm{L}$.

Waltheria indica $\mathrm{L}$.

\section{Herbs}

$\begin{array}{ll}\text { Leguminosae } & 9.41 \\ \text { Phyllanthaceae } & 12.69 \\ \text { Capparaceae } & 1.53 \\ \text { Opliaceae } & 4.53 \\ \text { Capparaceae } & 4.79 \\ \text { Capparaceae } & 8.36 \\ \text { Capparaceae } & 0.68 \\ \text { Apocynaceae } & 1.73 \\ \text { Vitaceae } & 4.9 \\ \text { Menispermaceae } & 34.84 \\ \text { Vitaceae } & 3.53 \\ \text { Malvaceae } & 7.94 \\ \text { Linaceae } & 18.38 \\ \text { Oleaceae } & 11.62 \\ \text { Rubiaceae } & 0.84 \\ \text { Vitaceae } & 3.79 \\ \text { Icacinaceae } & 8.05 \\ \text { Loganiaceae } & 26.32 \\ \text { Dilleniaceae } & 11.83 \\ \text { Vitaceae } & 6.15 \\ \text { Annonaceae } & 10.57 \\ \text { Rhamnaceae } & 7.52\end{array}$

$\begin{array}{ll}\text { Amaranthaceae } & 1.41 \\ \text { Acanthaceae } & 6.43 \\ \text { Poaceae } & 11.05 \\ \text { Acanthaceae } & 9.04 \\ \text { Nyctaginaceae } & 4.69 \\ \text { Apocynaceae } & 2.88 \\ \text { Commelinaceae } & 2.54 \\ \text { Commelinaceae } & 4.22 \\ \text { Orchidaceae } & 4.22 \\ \text { Poaceae } & 15.94 \\ \text { Poaceae } & 10.46 \\ \text { Colchicaceae } & 4.29 \\ \text { Apocynaceae } & 5.49 \\ \text { Acanthaceae } & 5.02 \\ \text { Acanthaceae } & 1.41 \\ \text { Rubiaceae } & 1.14 \\ \text { Euphorbiaceae } & 4.62 \\ \text { Leguminosae } & 2.01 \\ \text { Lamiaceae } & 2.28 \\ \text { Poaceae } & 7.91 \\ \text { Poaceae } & 23.33 \\ \text { Plumbaginaceae } & 1.74 \\ \text { Asparagaceae } & 64.61 \\ \text { Malvaceae } & 1.41 \\ \text { Malvaceae } & 0.87 \\ \text { Malvaceae } & 1\end{array}$

Taxonomically, a total of 102 plant species belonging to 90 genera and 46 families were recorded in the sacred forest (representative of tropical dry evergreen forest fragment of the southwest coast of Kanyakumari district) studied (Table 1). Among these, 36 (35.29\%) were trees, 18 (17.65\%) shrubs, 26 (25.49\%) herbs, and 22 were $(21.57 \%)$ climbers including lianas. In the tropical dry evergreen forest, Malvaceae and Rubiaceae was the dominant family with 8 species followed by Apocynaceae (7 species), Leguminosae (6 species), Acanthaceae and Poaceae (5 species each), Anacardiaceae, Capparaceae, Moraceae and Vitaceae (4 species each) were well represented in the study area. Phyllanthaceae was represented by three species, followed by 8 family of two species each, whereas 28 families were monospecific (Fig. 3). 


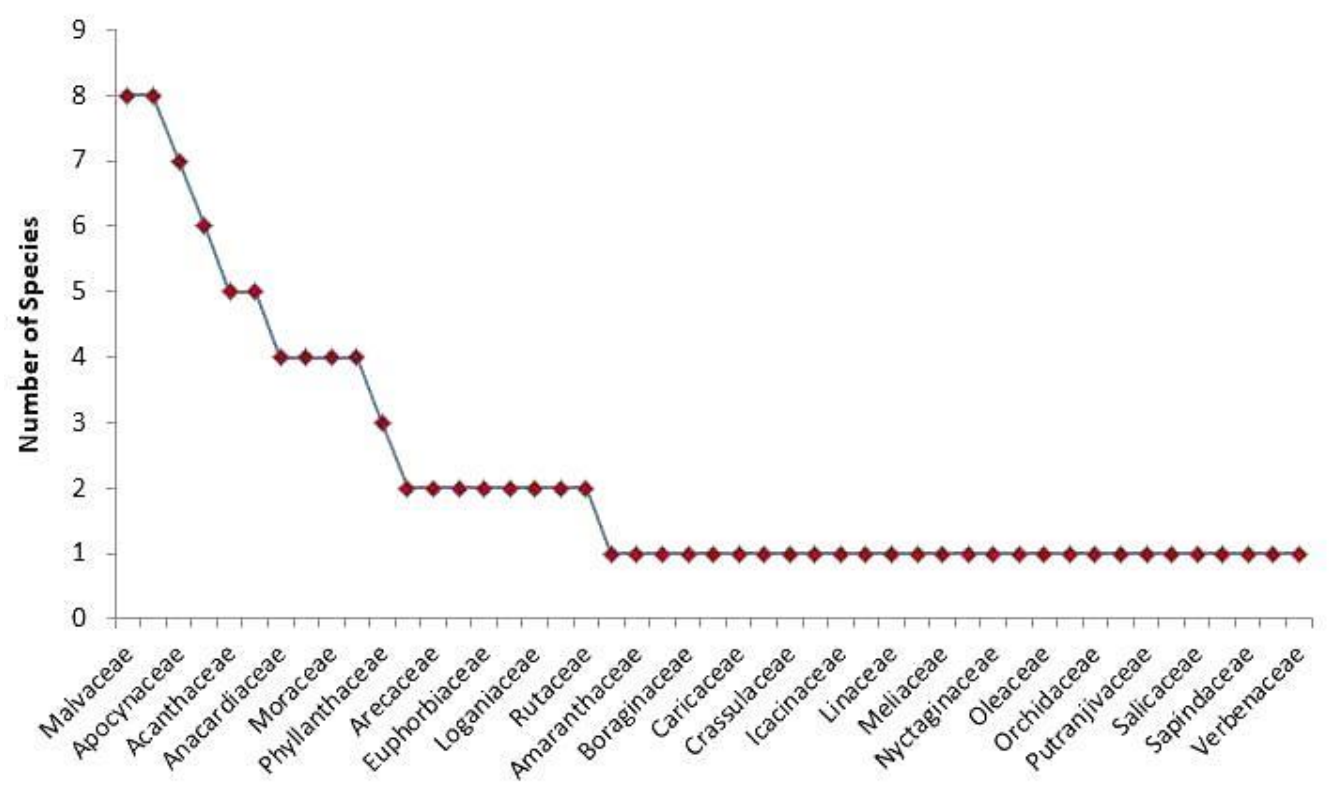

Figure 3. Dominance - distribution pattern of families in the study area.

In the present study, the majority of species (17 spp. $20-40 \mathrm{~cm}$ dph; $13 \mathrm{spp} .40-60 \mathrm{~cm}$ dph; $15 \mathrm{spp} .60-80 \mathrm{~cm}$ $\mathrm{dph}$ ) were represented by young individuals and species richness decreased with increase in dbh class, except in the case of mature trees beyond $>180 \mathrm{~cm}$ dbh (Fig. 4). In case of distribution pattern, the majority of the species showed a clumped distribution pattern and only $6-10 \%$ of the species were randomly distributed in the forest (Fig. 5). The clumpy vegetation is due to the canopy gaps forming a major source of disturbance (Armesto et al. 1986).

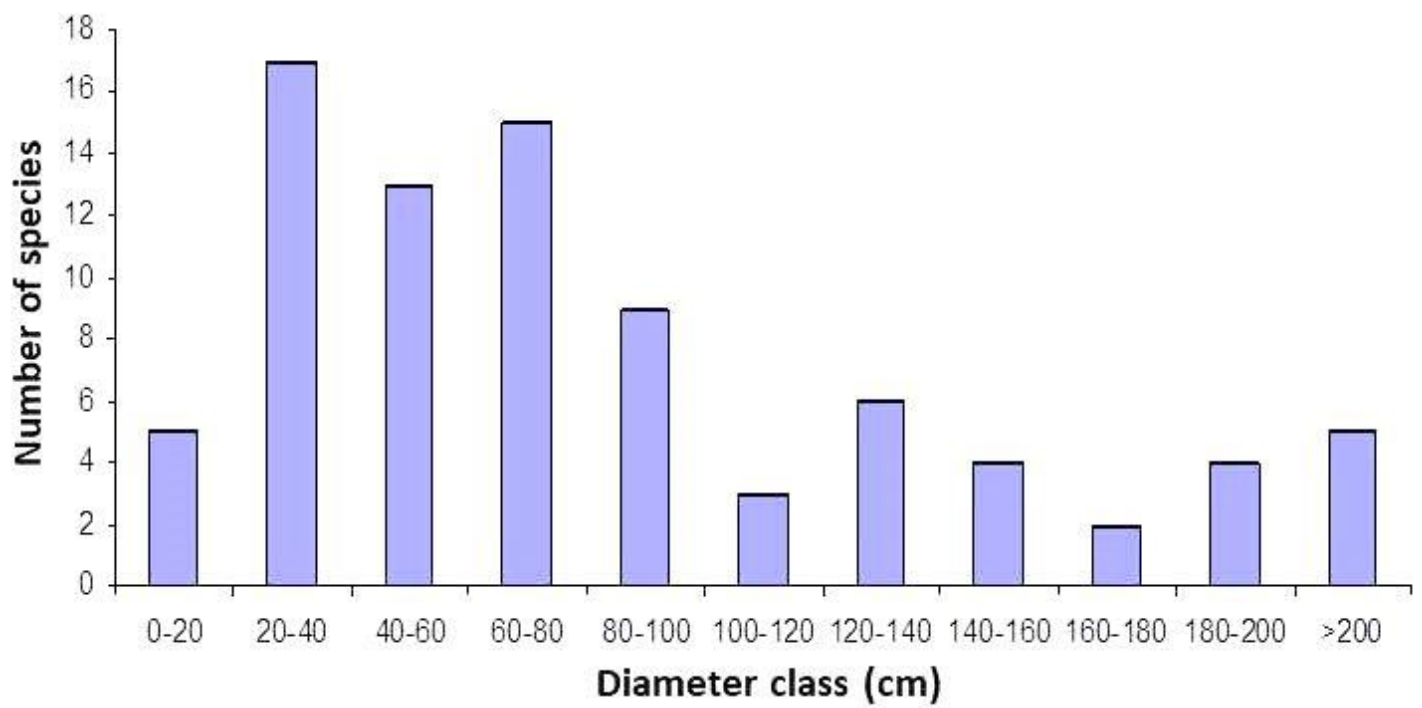

Figure 4. Distribution of species in different diameter classes in the study area.

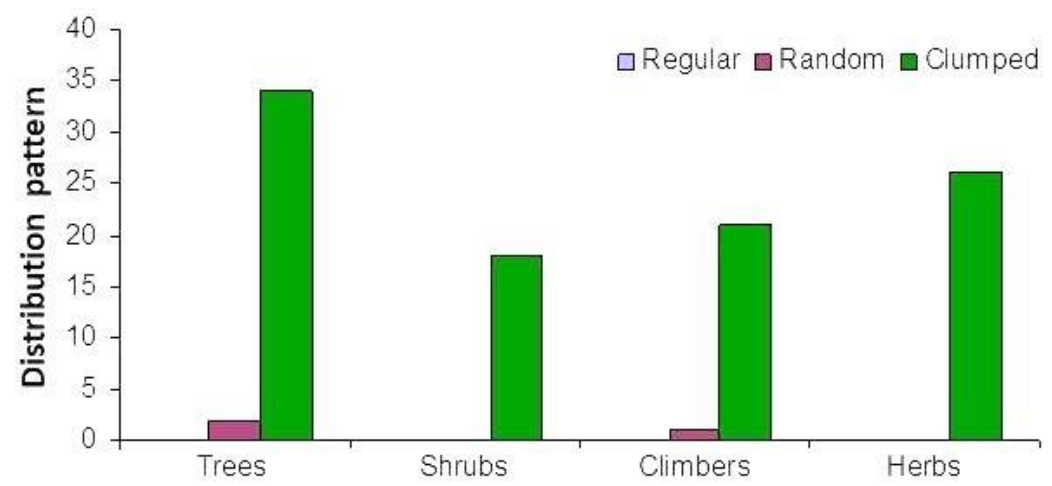

Figure 5. Distribution pattern of plant species in the study area. 
Density and basal cover

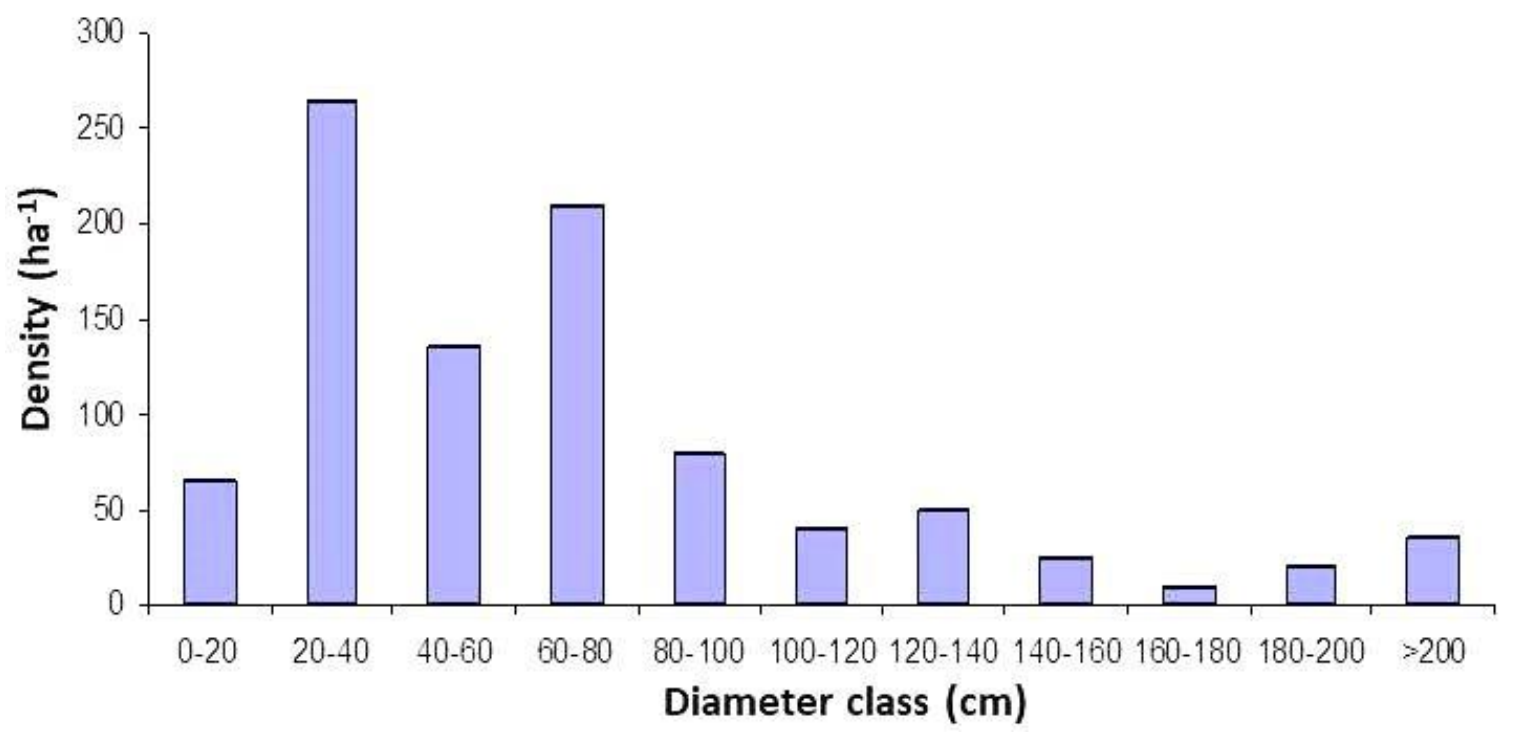

Figure 6. Distribution of density in different diameter classes in the study area.

Distribution of density in different girth classes is shown in figure 6. In the sacred forest, $65.24 \%$ of the stem was in the $20-60 \mathrm{~cm}$ dbh class and only $2.67 \%$ in $140-160,1.07 \%$ in $160-180,2.14 \%$ in $180-200$ and $3.74 \%$ in $>200 \mathrm{~cm}$ dbh classes respectively (Fig. 6). The study was more or less similar to the report of Upadhaya et al. (2004) which showed a maximum density of species in $515 \mathrm{~cm}$ dph classes. In Muppuram, 935 individuals of tree species encountered, nearly 50 percent of the species were represented by one or two stems. Drypetes sepiaria had the maximum number of individuals (135 stems), Manilkara hexandra (95 stems), Morinda coreia (80 stems), Tamilnadia uliginosa (75 stems), Adenanthera pavonina (50 stems), Tamarindus indica (40 stems) (Fig. 7). In the study area the density of young trees $(20-40 \mathrm{~cm} \mathrm{dbh}$ ) was much greater compared to the mature trees $(>160 \mathrm{~cm} \mathrm{dbh})$. However, despite this, the basal cover of young trees was much lower than that of mature trees $\left(0.07\right.$ versus $\left.31.05 \mathrm{~m}^{2} . \mathrm{ha}^{-1}\right)$. A sharp decrease in density with the increase in girth classes was reported from the sacred groves of Manipur (Khumbongmayum et al. 2005). The reports of Johnston \& Gillman (1995) in Kurupukari sacred grove; Valencia et al. (1994) in Amazonian Ecuador; Jamir (2000) in subtropical humid forest in Jaintia hills, Meghalaya; Pascal \& Pelissier (1996), Parthasarathy \& Karthikeyan (1997) in the sacred groves of Western Ghats also evaluated the same. Drypetes sepiaria was one of the dominant species in the study area and similar report was given by Sundarapandian \& Subbiah (2015) in tropical dry evergreen forests in Sivagangai district, Tamilnadu.

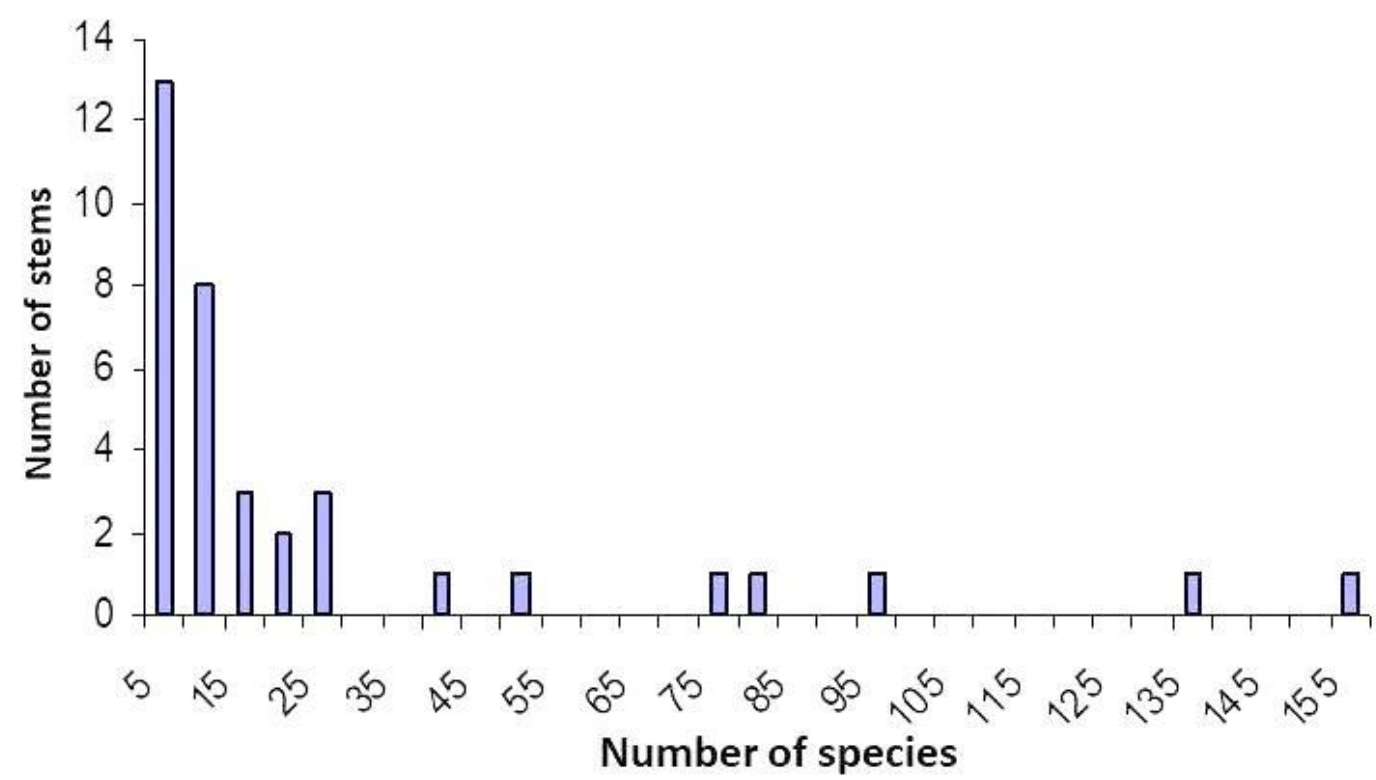

Figure 7. Species stem relationship in a hectare area of the sacred grove. 
Shannon-Weiner Diversity Index value was estimated to be 2.92 for trees, 2.72 for shrubs, 2.72 for climbers and 2.54 for herbs. Simpson's Dominance Index values for trees, shrubs, climbers and herbs were found to be 0.08, 0.08, 0.09, and 0.13 respectively. The estimated Species Evenness Index value was 0.81 for trees, 0.94 for shrubs, 0.88 for climbers and 0.78 for herbs. Whitaker Index values for trees, shrubs, climbers and herbs were calculated to be 6.88, 3.05, 3.41 and 3.93 (Table 2). High diversity and low Simpson's dominance value is due to human interferences. Similar statement was given by Parthasarathy et al. (1992), Visalakshi (1995) and Rampilla (2015) in the sacred groves of southern Western Ghats, tropical evergreen forest and Indrakiladri sacred grove.

Table 2. Density, basal area, dominance, diversity and evenness indices of plant species in the study area.

\begin{tabular}{lllll}
\hline Variable & Trees & Shrubs & Climbers & Herbs \\
\hline Density $\left(\mathrm{ha}^{-1}\right)$ & 925 & 1845 & 78750 & 931250 \\
Basal area $\left(\mathrm{m}^{2} \cdot \mathrm{ha}^{-1}\right)$ & 132.52 & 0.34 & - & - \\
Shannon's diversity index & 2.92 & 2.72 & 2.72 & 2.54 \\
Pielou's evenness index & 0.81 & 0.94 & 0.88 & 0.78 \\
Simpson's dominance index & 0.08 & 0.08 & 0.09 & 0.13 \\
Whittaker index & 6.88 & 3.05 & 3.41 & 3.93 \\
\hline
\end{tabular}

Dominance distribution pattern of Tree species

The dominance distribution yielded log-normal curves showing a high equitability and low dominance in the Muppuram forest (Fig. 8). The same curve was reported by Mishra et al. (2004) in the sacred grove of Meghalaya. This is because of the stability of the community. Drypetes sepiaria (IVI $=40.50)$ and Manilkara hexandra (IVI = 25.19) was the dominant and co-dominant species respectively, whereas Psidium guajava (IVI $=1.73$ ) was the least dominant species of the study area.

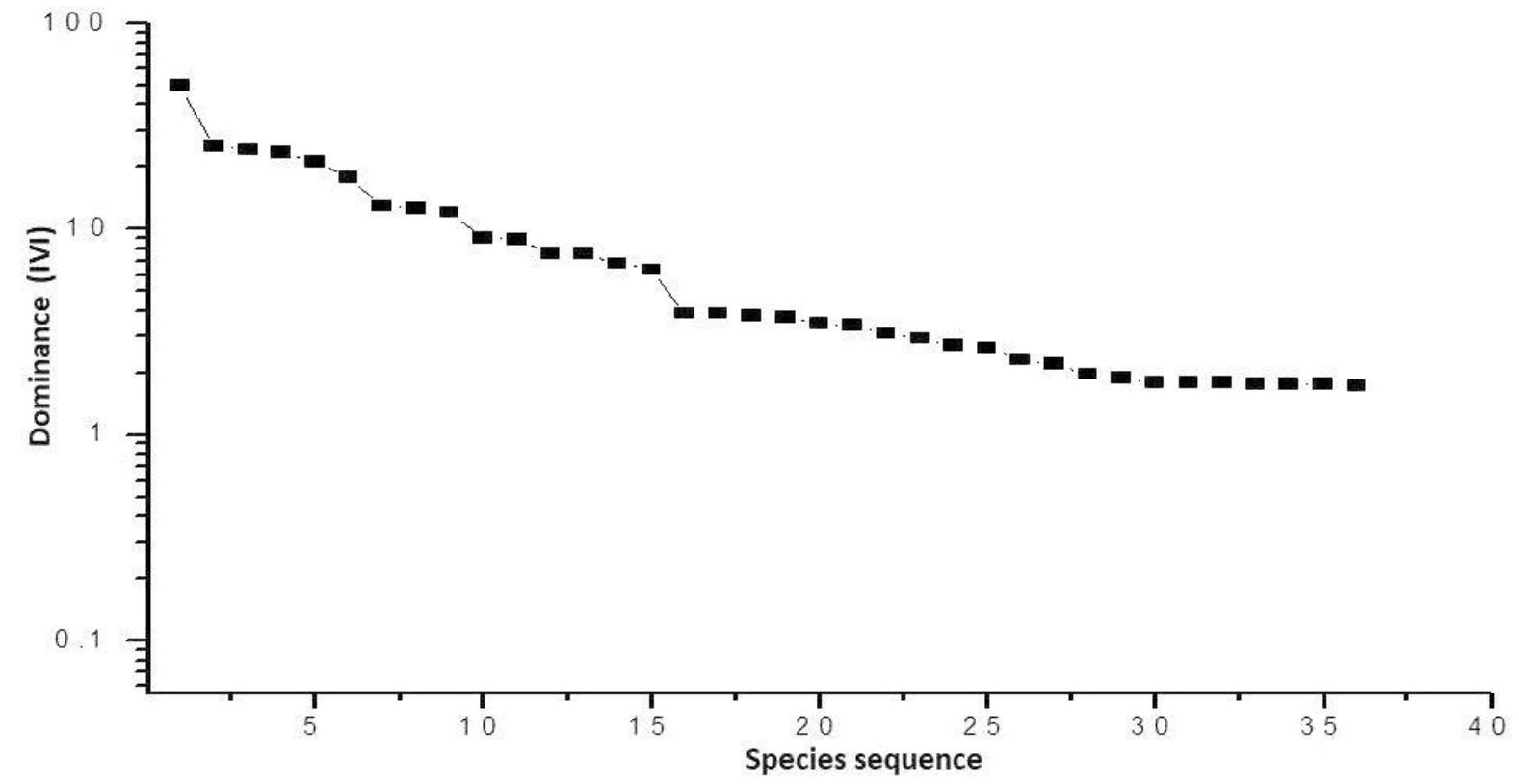

Figure 8. Dominance - diversity curves of trees in the study area.

\section{CONCLUSION}

A discussion on the tropical dry evergreen forest would be complete without assessing their present and future prospects. The analysis reveals the dominance of belief system over the preservation of grove proper. Signs of human impacts are unmistakable and vary in extent, viz. conversion into coconut based agroforestry system, ornate temple construction etc. The introduction of non-grove species, though observed only in two plots, is ominous at its bound to alter the native species composition. In conclusion, the present study has documented the prevalence of the sacred forest among the agricultural/urban societies. It further confirms that these forests have managed to survive up to the modern times but are struggling for survival now. Despite their alarming conservation status, the biodiversity conserved in them is significantly rich, varied and valuable.

Rappaport (1971) argued that the human societies have employed the concept of sacred to mould human behavior where the interests of the individual clash with those of forest/grove as a whole. In his opinion, the 
sacred forest is represented the ecological prudence against the profligacy of individuals. The study reveals that the very state belief system, which was scrupulously evolved to foster the biodiversity conservation, has initiated its nemesis too. Unless urgent and stem measures are taken, the time is not far-off that the "mini biosphere reserves" will turn to the "relicts of dying wisdom".

\section{ACKNOWLEDGEMENT}

The authors are thankful to the Head, Department of Botany, Nesamony Memorial Christian College, Marthandam for providing necessary facilities and encouragement.

\section{REFERENCES}

Ahmedullah M \& Nayar MP (1986) Endemic plants of the Indian region: Vol. 1. Peninsular India. Botanical Survey of India, Kolkata, India, pp. 26.

Armesto JJ, Mitchell JD \& Villogram C (1986) A comparison of spatial patterns of trees in tropical and temperate forests. Biotropica 18: 1-11.

Balasubramanian K \& Induchoodan NC (1996) Plant diversity in sacred groves of Kerala. Evergreen 36: 3-4.

Beddome RH (1868-1874) Icones Plantarum Indiae Orientalis. Ganz Brothers, Madras. p. 32

Burman RJJ (1992) The institution of sacred grove. Journal of Indian Anthropology and Society 27: 219-238.

Davis G \& Richardson D (1995) Mediterranean Type Ecosystems: The function of Biodiversity. Springer, Berlin, Germany.

Debabrata P, Sekhar BS \& Sharat KP (2014) Floral Diversity Conservation through Sacred Groves in Koraput District, Odisha, India: A Case Study. International Research Journal of Environment Sciences 3(9): 80-86.

Deepa MR, Sheema Dharmapal P \& Udayan PS (2016) Floristic diversities and medicinal importance of selected sacred groves in Thrissur district, Kerala. Tropical Plant Research 3(1): 230-242.

Deepa MR, Udayan PS \& Anilkumar KA (2017) Taxonomical and phytosociological studies on ChithalikavuA sacred grove, Thrissur district, Kerala. Tropical Plant Research 4(1): 20-30.

Gadgil M \& Vartak VD (1975) Sacred Groves of India-A Plea for Continued Conservation. Journal of the Bombay Natural History Society 72: 313-320.

Gadgil M \& Vartak VD (1976) Sacred groves of Western Ghats of India. Economic Botany 30: 152-160.

Gamble JS \& Fischer CEC (1915-1935) The Flora of the Presidency of Madras, Part I- II. Adlard and Son Ltd., London.

Gnanasekaran G, Nehru P \& Narasimhan D (2012) Angiosperms of Sendirakillai sacred grove (SSG), Cuddalore District, Tamilnadu, India. Check List 8: 113-129.

Jamir SA \& Pandey HN (2003) Vascular plant diversity in the sacred groves of Jaintia hills in Northeast India. Biodiversity and Conservation 12: 1497-1510.

Jamir SA (2000) Studies on plant biodiversity, community structure and population behavior of dominant tree species of some sacred groves of Jaintia hills, Meghalaya, Ph. D. Thesis. North-Eastern Hill University, Shillong, India.

Jeeva S, Kiruba S, Mishra BP, Kingston C, Venugopal N \& Laloo RC (2005b) Importance of weeds as traditional medicine in Kanyakumari district, Southern Western Ghats. Journal of Swamy Botanical Club 22: 71-76.

Jeeva S, Kiruba S, Mishra BP, Venugopal N, Das SSM, Sukumaran S, Regini GS, Kingston C, Kavitha A, Raj ADS \& Laloo RC (2006) Weeds of Kanyakumari district and their value in rural life. Indian Journal of Traditional Knowledge 5: 501-509.

Jeeva S, Kiruba S, Mishra BP, Venugopal N, Kharlukhi L, Regini GS, Das SSM \& Laloo RC (2005a) Diversity of medicinally important plant species under coconut plantation in the coastal region of Cape Comorin. Flora and Fauna 11: 226-230.

Johnston M \& Gillman M (1995) Tree population studies in low-diversity forests, Guyana.I. Floristic composition and stand structure. Biodiversity and Conservation 4: 339-362.

Kershaw KA (1973) Quantitative and Dynamic Plant Ecology. Edward Arnold, London, 286 p.

Khumbongmayum AD, Khan ML \& Tripathi RS (2005) Sacred groves of Manipur, Northeast, India: biodiversity value, status and strategies for their conservation. Biodiversity and Conservation 14: 15411582.

Margalef R (1958) Information theory in ecology. General Systematics 3: 36-71. 
Mehra A, Bajpai O \& Joshi H (2014) Diversity, utilization and sacred values of Ethno-medicinal plants of Kumaun Himalaya. Tropical Plant Research 1(3): 80-86.

Mishra BP, Tripathi OP, Tripathi RS \& Pandey HN (2004) Effect of anthropogenic disturbance on plant diversity and community structure of a sacred grove in Meghalaya, north east India. Biodiversity and Conservation 13: 421-436.

Mishra R (1968) Ecology Work Book. Oxford \& IBH Publishing Co., Calcutta, India.

Myers N (1993) Questions of mass extinction. Biodiversity and Conservation 2: 2-17.

Nayar MP (1959) The vegetation of Kanyakumari district. Bulletin of the Botanical Survey of India 1: 122-126.

Parthasarathy N \& Karthikeyan R (1997) Plant biodiversity inventory and conservation of two tropical dry evergreen forests on the Coromandal Coast, South India. Biodiversity and Conservation 6: 1063-1083.

Parthasarathy N, Kinhal V \& Kumar PL (1992) Plant species diversity and human impacts in the tropical wet evergreen forests of Southern Western Ghats. In: Indo-French workshop on Tropical forest ecosystems: natural functioning and anthropogenic impacts. French institute Pondicherry.

Pascal JP \& Pelissier R (1996) Structure and floristic composition of Tropical Evergreen forest in southern India. Journal of Tropical Ecology 12: 95-218.

Phillips EA (1959) Methods of Vegetation Study. Henry Holt and Co., New York, USA.

Phillips OL (1995) Evaluating turnover in Tropical forests. Science 268: 894-895.

Phillips OL (1997) The changing ecology of tropical forests. Biodiversity and Conservation 6: 291-311.

Pielou EC (1966) The measurement of diversity in different type of biological collections. Journal of Theoretical Biology 13: 131-144.

Prakash JW, Suman LL, Devi MSV, Premila AB, Anderson NA, Veni P, Essaki G, Amutha M, Rajeev R, Bensar K, Jeeva S, Williams BC, Regini GS \& Das SSM (2006) The medicinal plant diversity of Scott Christian College (Autonomous) Campus, Nagercoil, South Tamilnadu, India. Journal of Nature Conservation 18: 81-89.

Rabha D (2014) Species composition and structure of Sal (Shorea robusta Gaertn. f.) forests along distribution gradients of Western Assam, Northeast India. Tropical Plant Research 1(3): 16-21.

Raj ADS \& Sukumaran S (1997) Observations of the sacred groves of south Tamil Nadu. In: Abstracts of National Symposium on Natural Resources Management Systems. St. Joseph College, Thiruchirapalli, Tamilnadu.

Ramakrishnan PS, Saxena KG, Rao KS, Maikhuri RK \& Das AK (1998) Ethnic and Agricultural Biodiversity in north-east India. In: Partap T \& Sthapit B (eds) Managing Agrobiodiversity in the HKH Region. ICIMOD, Kathmandu, Nepal.

Ramanujam MP \& Cyril KPK (2003) Woody species diversity of four sacred groves in the Pondicherry region of South India. Biodiversity and Conservation 12: 289-299.

Ramesh BR \& Pascal JP (1991) Distribution of endemic arborescent evergreen species in the Western Ghats. In: The proceedings of the symposium on rare endangered and endemic plants of the Western Ghats. pp. 20-29.

Rampilla V, Khasim S, Mahammad \& Kakumanu B (2015) Floristic diversity and Phyto-sociological studies of Indrakiladri Sacred Grove in Krishna district, Andhra Pradesh, India. Journal of Pharmacy and Biological Sciences 10: 61-75.

Rappaport A (1971) The sacred in human evolution. Annual Review of Systematics and Ecology 2: 23-44.

Rastogi J, Rawat DS \& Chandra S (2015) Diversity of invasive alien species in Pantnagar flora. Tropical Plant Research 2(3): 282-287.

Rodgers WA (1994) The sacred groves of Meghalaya. Man in India 74: 339-348.

Sarkar M \& Devi A (2017) Analysis of medicinal and economic important plant species of Hollongapar Gibbon wildlife sanctuary, Assam, northeast India. Tropical Plant Research 4(3): 486-495.

Shannon CE \& Weiner W (1949) The Mathematical Theory of Communication. University of Illinois Press, Urbana, Illionis, pp. 1-117.

Simpson EH (1949) Measurement of diversity. Nature 8: 163: 688.

Solbrig OT (1991) From Genes to Ecosystems: A Research Agenda for Biodiversity. IUBS - SCOPE UNESCO, Harvard, Cambridge, Massachusetts, 124 p.

Sreeja K \& Unni PN (2016) Floristic diversity of Vallikkaattu Kaavu, a sacred grove of Kozhikode, Kerala, India. Journal of Ecology and Environmental Sciences 8: 175-183. 
Sukumaran S \& Jeeva S (2008) A floristic study on miniature sacred forests at Agastheeshwaram, Southern Peninsular India. EurAsian Journal of Biosciences 2: 66-72.

Sukumaran S, Jeeva S, Raj ADS \& Kannan D (2008) Floristicdiversity, conservation status and Economical value of miniature sacred groves in Kanyakumari District, Tamilnadu, Southern Peninsular India. Turkish Journal of Botany 32: 185-199.

Sundarapandian SM \& Subbiah S (2015) Diversity and tree population structure of tropical dry evergreen forests in Sivagangai district of Tamilnadu, India. Tropical Plant Research 2(1): 36-46.

Sundarapandian SM \& Swamy PS (1997) Plant biodiversity at low elevation evergreen and moist deciduous forests at Kodayar (Western Ghats, India). International Journal of Ecology and Environmental Sciences 23: 363-379.

Sundarapandian SM \& Swamy PS (2000) Forest ecosystem structure and composition along an altitudinal gradient in the Western Ghats, South India. Journal of Tropical Forest Science 12: 104-123.

Sundarapandian SM, Chandrasekaran S \& Swamy PS (2005) Phenological behaviour of selected tree species in tropical forests at Kodayar in the Western Ghats, Tamil Nadu, India. Current Science 88: 805-810.

Swamy PS, Sundarapandian SM, Chandrasekar P \& Chandrasekaran S (2000) Plant species diversity and tree population structure of a humid tropical forest in Tamilnadu, India. Biodiversity and Conservation 9: 16431669.

Tripathi RS (2001) Sacred groves: Community biodiversity conservation model in north-east India. In: Ganeshaiah, KN, UmaShanker R \& Bawa KS (eds) Tropical Ecosystems: Structure, Diversity and Human Welfare (Supplement), Proceedings of the International Conference on Tropical Ecosystems. Ashoka Trust for Research in Ecology and Environment (ATREE), Bangalore. pp. 104-107.

Upadhaya K, Pandey RN, Law PS \& Tripathi RS (2004) Diversity and population characteristics of woody species in subtropical humid forests exposed to cultural disturbances in Meghalaya, Northeast, India. Tropical Ecology 45: 475-486.

Valencia R, Balslev H, Paz YG \& Mino C (1994). High tree alpha-diversity in Amazonian Ecuador. Biodiversity and Conservation 3: 21-28.

Visalakshi N (1995) Vegetation analysis of two tropical dry evergreen forests in Southern India. Tropical Ecology 36: 117-127.

Whittaker RH (1975) Communities and Ecosystems. Macmillan Publishing Company, New York.

Younes T (1992) Ecosystem function of Biodiversity: a progress reports on the IUBS- SCOPE- ENESCO programme. Bulletin International 21: 6-2. 